\title{
TOKSISITAS SEL UTUH DAN EXTRACELLULAR PRODUCT (ECP) Streptococcus agalactiae $\beta$-HEMOLITIK DAN NON-HEMOLITIK PADA IKAN NILA (Oreochromis niloticus)
}

\author{
Achmad Suhermanto ${ }^{* * *}$, Sukenda**\#, Muhammad Zairin Jr."), Angela Mariana Lusiastuti***), \\ dan Sri Nuryati* \\ *) Program Pascasarjana IImu Akuakultur, Fakultas Perikanan dan IImu Kelautan, Insitut Pertanian Bogor \\ Jalan Agatis, Kampus Dramaga, Bogor 1680, Jawa Barat \\ * Politeknik Kelautan dan Perikanan Sorong, KKD-BP Kesehatan Ikan dan Lingkungan \\ Jl. K. Pattimura, Tj. Kasuari, Sorong, Papua Barat \\ **) Balai Riset Perikanan Budidaya Air Tawar dan Penyuluhan Perikanan \\ Jl. Sempur No. 1, Bogor 16129
}

(Naskah diterima: 9 Januari 2019; Revisi final: 14 Februari 2019; Disetujui publikasi: 15 Februari 2019)

\begin{abstract}
ABSTRAK
Bakteri Streptococcus agalactiae tipe $\beta$-hemolitik dan non-hemolitik menjadi agen penyebab infeksi streptococcosis yang mengakibatkan kematian dan kerugian besar pada budidaya ikan nila. Penelitian ini bertujuan untuk membandingkan toksisitas sel utuh dan extracellular product (ECP) bakteri $\beta$-hemolitik dan non-hemolitik yang diinjeksikan pada ikan nila. Karakterisasi S. agalactiae berdasarkan SNI dan API 20 STREP, serta pemisahan protein dengan metode SDS-PAGE. Pengujian toksisitas dilakukan dengan cara menginjeksikan sel utuh dan ECP S. agalactiae secara intraperitoneal (IP) dengan dosis $0,1 \mathrm{~mL}$ ekor $^{-1}$. Hasil uji biokimia, dan konfirmasi dengan API 20 STREP menunjukkan bahwa semua isolat positif S. agalactiae. Fraksinasi protein pada sel utuh bakteri diperoleh pita protein masing-masing sebanyak sembilan dan tujuh pita pada tipe $\beta$-hemolitik dan non-hemolitik. Fraksinasi ECP teridentifikasi pada $\beta$-hemolitik sebanyak tujuh pita dan non-hemolitik empat pita protein. Konsentrasi protein sel utuh dan ECP $\beta$-hemolitik lebih besar dibandingkan bakteri non-hemolitik. Gejala abnormalitas lebih cepat terjadi pada ikan nila yang diinjeksi ECP bakteri $\beta$-hemolitik dan berbanding lurus dengan kematian sebanyak $91 \% 100 \%$ pada jam ke13 pascainjeksi. Hasil ini menunjukkan bahwa ECP bakteri S. agalactiae $\beta$-hemolitik lebih virulen dibandingkan tipe non-hemolitik. Hingga akhir pemeliharaan tidak ada kematian pada ikan yang diinjeksi sel utuh bakteri S. agalactiae $\beta$-hemolitik dan non-hemolitik. Studi histopatologi ikan yang diinjeksi ECP S. agalactiae pada organ hati, limpa, otak, dan ginjal menunjukkan adanya kongesti, hemoragi, dan nekrosis.
\end{abstract}

KATA KUNCI: fraksinasi; gejala klinis; Streptococcus agalactiae; sintasan; ikan nila

ABSTRACT: Toxicity of whole cells and extracelluar product (ECP) of $\beta$-hemolytic and non-hemolytic Streptococcus agalactiae in tilapia (Oreochromis niloticus). By: Achmad Suhermanto, Sukenda, Muhammad Zairin Jr., Angela Mariana Lusiastuti, and Sri Nuryati

The $\beta$-hemolytic and non-hemolytic biotype of Streptococcus agalactiae are the agents that cause streptococcosis infection which resulted in high mortality and major losses in tilapia culture. This study aimed to compare the toxicity of whole cell and extracellular product (ECP) $\beta$-hemolytic and non-hemolytic bacteria from injected tilapia. Characterization of $\mathbf{S}$. agalactiae was based on SNI and API 20 STREP and protein separation by SDS-PAGE method. Toxicity test was carried out by injecting whole cells and ECP S. agalactiae intraperitoneally with a dose of $0.1 \mathrm{~mL}$ fish1. The results of biochemical tests, with confirmation by API 20 STREP showed that all isolates were positive for $\mathrm{S}$. agalactiae. Protein fractionation of whole bacterial cells obtained as many as nine and seven bands of protein in $\beta$-hemolytic and non hemolytic biotype, respectively. ECP fractionation was identified in b-hemolytic biotype as many

\footnotetext{
\# Korespondensi: Program Pascasarjana IImu Akuakultur,

Fakultas Perikanan dan Ilmu Kelautan, Insitut Pertanian Bogor.

Jalan Agatis, Kampus Dramaga, Bogor 1680, Jawa Barat, Indonesia.

Tel. + 622518622935

E-mail: sukenda@ipb.ac.id
} 


\begin{abstract}
as seven bands and four protein bands in non-hemolytic. The whole cell protein concentration and ECP $\beta$-hemolytic were higher than non-hemolytic bacteria. Symptoms of abnormalities occurred faster in tilapia which was injected with ECP $\beta$-hemolytic bacteria and had positive correlation with $91 \% 100 \%$ mortalities at the $13^{\text {th }}$ hours post-injection. This results indicated that ECP of $\mathbf{S}$. agalactiae b-hemolytic are more virulent than non-hemolytic. Until the end of the trial, there were no deaths in fish injected with whole cells of $\beta$-hemolytic and non-hemolytic $\mathbf{S}$. agalactiae. Histopathological studies of ECP-injected fish S. agalactiae in the liver, spleen, brain, and kidneys showed congestion, hemorrhage, and necrosis.
\end{abstract}

\title{
KEYWORDS: fractionation; clinical sign; Streptococcus agalactiae; survival rate; tilapia
}

\section{PENDAHULUAN}

Infeksi streptococcosis yang disebabkan bakteri streptococcus menjadi permasalahan besar dalam budidaya ikan air tawar di dunia termasuk Indonesia terutama pada ikan nila (Amal \& Zamri-Saad, 2011; Lusiastuti et al., 2014; Pradeep et al., 2016). Ciri khas gejala yang muncul pada ikan positif terinfeksi streptococcosis yaitu peradangan otak (meningoensefalitis), mata menonjol (pop-eye), hilangnya nafsu makan, eksoptalmia lateral atau bilateral, perdarahan mata, kekeruhan pada kornea, perut buncit, sumsum tulang belakang melengkung membentuk huruf $C$, kekakuan, berenang tidak menentu (erratic), berputar (whirling), dan pendarahan di dasar sirip (Amal \& Zamri-Saad, 2011; Li et al., 2014). Streptococcus agalactiaemerupakan patogen penting penyebab streptococcosis yang menimbulkan kematian dan kerugian besar pada budidaya ikan nila (Sukenda et al., 2015; Kannika et al., 2017). Bakteri S. agalactiae Group B Streptococcus (GBS) termasuk dalam kelompok bakteri Gram positif yang tidak membentuk spora, tidak bersifat asam, non motil, $\beta$-hemolitik, dan non-hemolitik berukuran diameter 0,6-1,2 $\mu \mathrm{m}$ (Pereira et al., 2013).

Identifikasi isolat bakteri $\mathrm{S}$. agalactiae dan S. iniae di berbagai belahan dunia telah dilakukan dan diketahui tingkat prevalensi $\mathrm{S}$. agalactiae lebih besar pada ikan tilapia dari pada S. iniae (Sheehan et al., 2009). Berdasarkan karakteristik biokimia dan fenotip, bakteri ini terbagi dalam dua kluster yaitu biotipe-1 ( $\beta$-hemolitik) yang banyak menyerang budidaya ikan di kawasan Asia dan biotipe-2 (non-hemolitik) yang dilaporkan menyebabkan kematian pada budidaya ikan nila hampir di seluruh dunia (Sheehan et al., 2009; Delannoy et al., 2014). S. agalactiae tipe $\beta$-hemolitik identik dengan serotipe la ditemukan di kawasan Asia Tenggara dan tersebar luas di Thailand (Kayansamruaj et al., 2015), Malaysia (Noraini et al., 2013; Amal et al., 2015), banyak menyebabkan kematian massal pada budidaya ikan nila. Penelitian terhadap ikan nila dengan gejala streptococcosis di Indonesia mulai dilakukan pada tahun 2009 dan diketahui bakteri tipe nonhemolitik lebih dominan dalam memberikan dampak kematian nila hingga 85\% (Taukhid \& Purwaningsih, 2009).
Beberapa kajian tentang patogenisitas telah dilakukan pada bakteri S. agalactiae, dan faktor virulensi menjadi salah satu faktor penting penyebab kematian pada ikan nila (Delannoy et al., 2014; Kayansamruaj et al., 2014, Kannika et al., 2017). Perbedaan virulensi pada kedua tipe ini belum diketahui dominan faktor penyebabnya. Virulensi pada bakteri Gram positif (S. agalactiae) diketahui pada komponen eksotoksin extracellular product (ECP) dan toksin lainnya, sedangkan pada bakteri Gram negatif adalah lipopolysaccharide (LPS)/endotoksin yang bersifat lebih virulen (Williams et al., 2003). Penelitian ini bertujuan untuk membandingkan toksisitas sel utuh dan extracellular product (ECP) bakteri $\beta$-hemolitik dan non-hemolitik, gejala klinis dan histopatologi pada ikan nila.

\section{BAHAN DAN METODE}

Penelitian dilaksanakan dari bulan November 2017April 2018 di Instalasi Riset Pengendalian Penyakit Ikan (IRP2I) Depok, Jawa Barat. Pengujian profil dan konsentrasi protein dilakukan di laboratorium Pusat Antar Universitas (PAU) Institut Pertanian Bogor (IPB).

\section{Ikan Uji}

Ikan nila (Oreochromis niloticus) strain Nirwana-III sebagai ikan uji berasal dari Balai Pengembangan dan Pemacuan Stok Ikan Nila dan Mas Wanayasa, Jawa Barat. Ikan uji dengan bobot 17,44 $\pm 1.400 \mathrm{~g}$; dipelihara dengan kepadatan 15 ekor akuarium ${ }^{-1}$ ukuran $60 \mathrm{~cm} x$ $35 \mathrm{~cm} \times 35 \mathrm{~cm}$, dan ketinggian air $25 \mathrm{~cm}$. Aklimatisasi dilakukan selama 14 hari hingga ikan siap digunakan. Ikan uji yang digunakan bebas atau specific pathogen free (SPF) terhadap bakteri $\mathrm{S}$. agalactiae. Pengujian dilakukan pada lima ekor ikan dengan mengisolasi organ mata, otak, dan ginjal ikan kemudian dikultur pada media brain heart infussion agar (BHIA), hasilnya tidak ditemukan S. agalactiae pada semua organ.

\section{Bakteri}

Bakteri S. agalactiae berasal dari sampel ikan nila (0. niloticus) saat terjadi wabah streptococcosis di berbagai daerah dengan organ target yang diisolasi berasal dari otak, ginjal anterior, dan mata, kemudian 
Tabel 1. Kode dan asal isolat bakteri

Table 1. Code and source of bacteria

\begin{tabular}{ccc}
\hline $\begin{array}{c}\text { Kode perlakuan } \\
\text { Code of treatments }\end{array}$ & $\begin{array}{c}\text { Kode isolat } \\
\text { Code of isolates }\end{array}$ & $\begin{array}{c}\text { Asal } \\
\text { Source }\end{array}$ \\
\hline B & NP1050 & Danau Sentani, Papua (Sentani Lake, Papua) \\
E & $N_{14} G$ & Waduk Cirata, Jawa Barat (Cirata Lake, West Java) \\
G & NT010 & Tasikmalaya, Jawa Barat (Tasikmalaya, West Java) \\
I & SG01-16 & Muaro Jambi, Jambi \\
\hline
\end{tabular}

dikultur pada media BHIA (Oxoid Ltd, UK) (Tabel 1), diinkubasi pada suhu $28^{\circ} \mathrm{C}$ selama 24 jam (SNI, 2009). Sebelum digunakan, empat isolat dilakukan Postulat koch's sebanyak dua kali dengan cara menginjeksikan bakteri pada ikan nila secara intraperitoneal (IP) dengan dosis $0,1 \mathrm{~mL}$ ekor ${ }^{-1}$. Isolasi organ target dilakukan ketika ikan sudah mengalami gejala streptococcosis.

Uji fenotipe $S$. agalactiae dilakukan berdasarkan metode standar (SNI, 2009). Aktivitas katalase diuji dengan mereaksikan bakteri dengan hidrogen peroksida 3\% Katalase positif ditunjukkan dengan adanya gelembung saat terjadi reaksi (Kannika et al., 2017). Uji konfirmasi menggunakan API 20 Strep System (bioMérieux Industry, Hazelwood, USA) sesuai protokol, data yang diperoleh diidentifikasi menggunakan software (https://apiweb. biomerieux.com). Penentuan biotipe bakteri dilakukan dengan pengujian aktivitas hemolitik yaitu isolat dikultur pada media blood agar base yang dicampur dengan $5 \%(v / v)$ darah kambing, diinkubasi selama 24 jam pada suhu $37^{\circ} \mathrm{C}$. Indikator zona lisis pada media blood agar base menunjukkan isolat tersebut $\beta$-hemolitik.

\section{Pengujian Toksisitas ECP dan Sel Utuh pada Ikan Nila}

Pengujian toksisitas dilakukan menggunakan sel utuh dan ECP S. agalactiae, yang dinjeksikan secara IP pada 15 ekor ikan dengan dosis $0,1 \mathrm{~mL}^{\text {ekor }}{ }^{-1}$, dan dilakukan pemeliharaan ikan selama 21 hari. Pengamatan gejala klinis hingga kematian ikan dan perubahan pola renang dilakukan hingga hari terakhir masa pemeliharaan.

\section{Isolasi Extracelluar Product (ECP)}

Isolasi ECP mengacu pada Hardi (2011), bakteri dikultur dalam media cair BHI $10 \mathrm{~mL}$, diinkubasi selama 24 jam pada suhu $28^{\circ} \mathrm{C}-30^{\circ} \mathrm{C}$. Bakteri yang tumbuh kemudian disentrifugasi dengan kecepatan $10.000 \mathrm{~g}$ selama 30 menit. Supernatan dan sel utuh bakteri dipisahkan dengan penyaringan menggunakan filter paper $0,22 \mu \mathrm{m}$. Hasil filtrasi digunakan untuk pengujian toksisitas ECP, sedangkan sel utuh bakteri dibilas sebanyak tiga kali dengan PBS sebelum dilakukan pengujian pada ikan nila. Ikan diinjeksi ECP dan sel utuh bakteri secara IP dengan dosis $0,1 \mathrm{~mL}^{\mathrm{ikan}}{ }^{-1}$.

\section{Fraksinasi dan Konsentrasi Protein Sel Utuh dan ECP}

Protein secara umum diukur menggunakan metode Bradford (1976) dan Sugiani (2012). Sebanyak $100 \mu \mathrm{L}$ sampel ditambahkan $1 \mathrm{~mL}$ pereaksi Bradford kemudian di-vortex dan diukur absorbansinya pada panjang gelombang $595 \mathrm{~nm}$. Larutan stok pereaksi Bradford dibuat dengan cara melarutkan $350 \mathrm{mg}$ serva blue $\mathrm{G}$ ke dalam $100 \mathrm{~mL}$ etanol 95\%kemudian ditambahkan 200 $\mathrm{mL}$ phosphoric acid $88 \%$ Sebanyak $30 \mathrm{~mL}$ larutan stok diambil dan ditambahkan $425 \mathrm{~mL}$ akuades, $15 \mathrm{~mL}$ etanol $95 \%$ dan $30 \mathrm{~mL}$ phosphoric acid $88 \%$ Konsentrasi protein contoh dihitung berdasarkan kurva standar yang dibuat dari bovine serum albumin (BSA). Protein pada tahap pemurnian diamati dengan mengukur serapan pada panjang gelombang $280 \mathrm{~nm}$.

Elektroforesis dilakukan mengikuti metode Laemmli (1970); Zhang \& Austin (2000) dengan tahapan persiapan gel pemisah (10\%): 3,34 mL larutan A [30\% (b/v) akrilamid dan $0,8 \%(\mathrm{~b} / \mathrm{v})$ bis-akrilamid]; $2,5 \mathrm{~mL}$ larutan B (1,5 M Tris-Cl pH 8,8; 0,4\%SDS) ditambah 50 $\mu \mathrm{L}$ APS $10 \%$ dan $5 \mu \mathrm{L}$ TEMED dituangkan ke dalam cetakan gel. Stacking gel (5\%): 0,67 mL larutan C (1 M Tris- $\mathrm{Cl} \mathrm{pH}$ 6,8 dan 0,4\% SDS); 2,3 mL akuades; $30 \mu \mathrm{L}$ APS $10 \%$; dan $5 \mu$ L TEMED dituang di atas gel pemisah yang sudah beku kemudian dipasang sisir. Bufer elektroforesis berisi Tris $25 \mathrm{mM}$, glisin $192 \mathrm{mM}$, dan SDS 0,1\% yang diatur pada $\mathrm{pH} 8,3$.

Pemisahan protein dilakukan dengan cara protein sampel $(20 \mu \mathrm{L})$ dicampur $5 \mu \mathrm{L}$ bufer sampel $(60 \mathrm{mM}$ Tris-Cl pH 6,8 25\% gliserol; 2\%SDS; 14,4 mM 2merkaptoetananol; dan 0,1\% bromfenol biru), dididihkan selama 2-3 menit dan dimasukkan ke dalam gel. Protein dipisahkan dengan memberikan aliran listrik (125 mA dan 150 V). Gel kemudian diwarnai dengan perak nitrat. 


\section{Mortalitas}

Perhitungan jumlah kematian ikan dilakukan menggunakan rumus:

$$
M(\%)=\frac{(\mathrm{No}-\mathrm{Nt})}{\mathrm{No}} \times 100
$$

Keterangan (Note):

M : mortalitas/mortality (\%)

No : jumlah ikan yang hidup pada awal pengamatan (ekor)

$\mathrm{Nt}$ : jumlah ikan yang hidup pada akhir pengamatan (ekor)

Rerata waktu kematian/mean time to death (MTD) dihitung berdasarkan Nitimulyo et al. (2005).

\section{Gejala Klinis}

Pengamatan gejala klinis makroskopis berupa perubahan tingkah laku pola berenang, perubahan anatomi organ luar (kondisi permukaan tubuh, kondisi mata, dan warna tubuh).

\section{Histopatologi}

Analisis histopatologi dilakukan pada organ hati, limpa, otak, dan ginjal ikan nila. Organ direndam dalam $10 \%$ netral buffer formalin (NBF) semalaman pada suhu ruang. Jaringan kemudian didehidrasi, ditanam dalam parafin dan dipotong dengan tebal $5 \mu$ m menggunakan Rotary MicrotomeHisto Line MRS 3500. Pewarnaan menggunakan hematoxylin dan eosin (HE), hasil histopatologi dievaluasi sesuai standar.

\section{Analisis Data}

Penelitian dilakukan dengan metode eksperimental menggunakan rancangan acak lengkap (RAL) terdiri atas delapan perlakuan. Empat perlakuan menggunakan sel utuh bakteri dengan kode B, E, G, dan I, perlakuan lainnya menggunakan ECP bakteri dengan kode $B 1$, E1, G1, dan I1. Setiap perlakuan dilakukan pengulangan sebanyak tiga kali. Data yang diperoleh ditabulasi dan dianalisis menggunakan program M icrosoft excel 2013. Pengaruh perlakuan dianalisis dengan sidik ragam (ANOVA) dengan bantuan Software Minitab versi 17. Analisis yang menunjukkan pengaruh nyata, dilanjutkan dengan uji Fisher pada taraf kepercayaan 95\% Hasil uji API 20 STREP dan berat molekul protein dianalisis secara deskriptif kualitatif.

\section{HASIL DAN BAHASAN}

Hasil uji biokimia menunjukkan semua isolat yang diuji katalase dan motilitas diperoleh hasil negatif, pewarnaan Gram positif dan uji fermentatif positif. Uji aktivitas hemolitik menunjukkan isolat B (NP1050) dan I (SG01-16) positif $\beta$-hemolitik, sedangkan isolat $\mathrm{N}_{14} \mathrm{G}$ dan NT010 tipe non-hemolitik (Gambar 1). Hasil uji tersebut sama dengan penelitian yang telah dilakukan pada bakteri $\mathrm{S}$. agalactiae yang diisolasi dari ikan nila (Al Harbi, 2016; Kannika et al., 2017). Uji konfirmasi terhadap empat isolat dengan API 20 STREP diperoleh hasil $84,6 \% 98,1 \% \mathrm{~S}$. agalactiae. Bakteri $\beta$ hemolitik memiliki kemampuan menghidrolisis gula lebih banyak daripada non-hemolitik termasuk Trehalose, dan amidon/starch, hal ini sesuai penelitian Sheehan et al. (2009) pada S. agalactiae.

Fraksinasi sel utuh bakteri dan ECP S.agalactiae dilakukan menggunakan SDS-PAGE untuk mengetahui berat molekul (BM) protein pada sel utuh dan ECP bakteri (Gambar 2). BM protein sel utuh S.agalactiae berada pada kisaran 13.93-150 kDa (Tabel 2), sedangkan sampel ECP bakteri tipe $\beta$-hemolitik berkisar antara

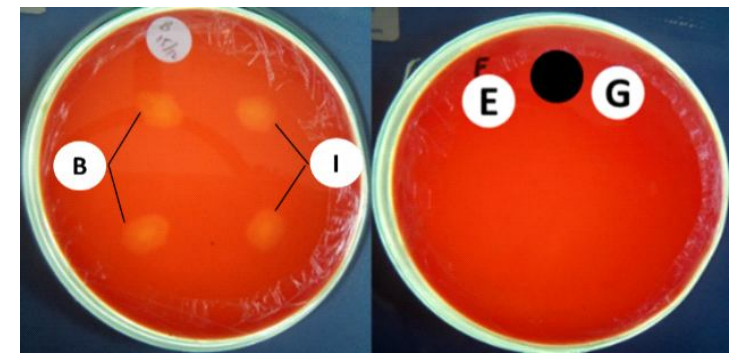

Keterangan (Note): M: marker; B: NP1050; G: NT010; I: SG01-16; $E: N_{14} G ; B 1: E C P$ NP1050; G1: ECP NT010; I1: ECP SG01-16; E1: ECP N ${ }_{14} \mathrm{G}$

Gambar 1. Aktivitas bakteri $\beta$-hemolitik (B, I) (kiri) dan non-hemolitik (E, G).

Figure 1. $\quad \beta$-hemolytic $(B, I)$ (left) and nonhemolytic $(E, G)$ (right) activity on blood agar.

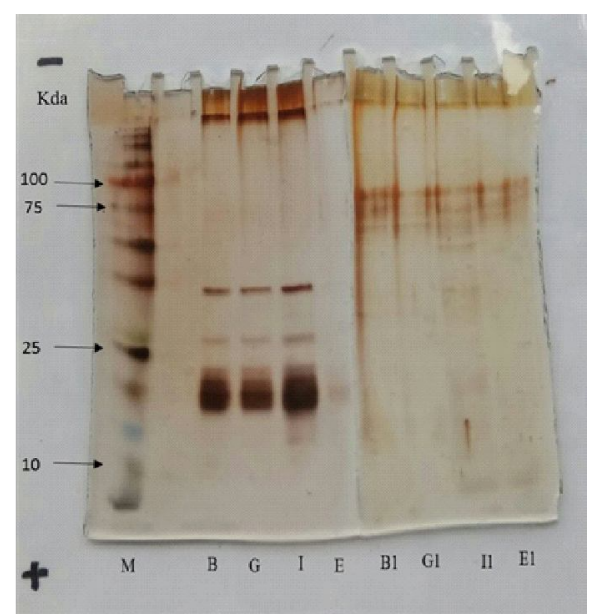

Gambar 2. Hasil fraksinasi protein dari sel utuh dan ECP bakteri.

Figure 2. Result of protein fractionation of whole cells and ECP. 
Tabel 2. Berat molekul protein sel utuh bakteri

Table 2. Molecular weight of protein in whole cell of bacteria

\begin{tabular}{cccccc}
\hline \multirow{5}{*}{$\begin{array}{c}\text { Berat molekul } \\
\begin{array}{c}\text { Molecular weight } \\
\text { (KDa) }\end{array}\end{array}$} & \multicolumn{5}{c}{$\begin{array}{c}\text { Perlakuan (kode bakteri) } \\
\text { Treatments (Code of bacteria) }\end{array}$} \\
\cline { 2 - 5 } & $\mathbf{B}$ & $\mathbf{I}$ & $\mathbf{E}$ & $\mathbf{G}$ & Protein \\
\hline 150.00 & + & + & + & + & Pili backbone protein* \\
79.00 & + & + & - & - & CylE protein** \\
65.92 & + & + & + & + & BL/UD \\
38.66 & + & + & + & + & BL/UD \\
24.00 & + & + & + & + & CAMP Protein** \\
19.01 & + & + & + & + & BL/UD \\
17.14 & + & + & + & + & BL/UD \\
15.45 & + & + & - & - & C protein alpha** \\
13.93 & + & + & + & + & BL/UD \\
\hline
\end{tabular}

Keterangan (Note): * Rosini \& Margarit (2015); **Doran \& Nizet (2004); BL/UD: belum diketahui (undetected)

32.00-85.41 kDa dan 59.43-85.41 kDa pada bakteri non-hemolitik (Tabel 3).

Hasil fraksinasi protein pada sel utuh bakteri S. agalactiae menunjukkan jumlah pita protein yang muncul sebanyak sembilan pita ( $\beta$-hemolitik) dan tujuh pita (non-hemolitik). Bakteri $\beta$ dan non-hemolitik memiliki pita protein yang sama pada BM $150 \mathrm{kDa}$ yang diperkirakan identik dengan pili backbone protein (Rosini \& Margarit, 2015), dan BM 24 kDa kemungkinan identik dengan CAMP protein (Doran \& Nizet, 2004).

Pili backbone protein berfungsi meningkatkan penempelan patogen pada permukaan keras atau jaringan inang, sedangkan CAMP factor yang menjadi faktor virulensi penting dan merupakan protein yang disekresikan untuk membentuk pori-pori di sel inang, mempromosikan kerusakan, dan invasi pada jaringan (Rajagopal, 2009). Penelitian berat molekul protein sel utuh $\mathrm{S}$. agalactiae $\mathrm{N}_{14} \mathrm{G}$ yang diinkubasi selama 72 jam pada suhu $28^{\circ} \mathrm{C}-30^{\circ} \mathrm{C}$ diperoleh sebanyak 10 pita protein dengan berat molekul 15,97-111,86 kDa (Sugiani, 2012). Lama inkubasi berpengaruh terhadap kepadatan bakteri $\mathrm{N}_{14} \mathrm{G}$, inkubasi dalam rentang waktu 24 jam pertumbuhan bakteri sebesar $64,13 \times 10^{9} \mathrm{CFU} /$ $\mathrm{mL}$; sedangkan pada waktu 72 jam pertumbuhannya mencapai $1,03 \times 10^{11} \mathrm{CFU} / \mathrm{mL}$, kondisi ini kemungkinan berpengaruh terhadap profil protein bakteri. Hasil

Tabel 3. Berat molekul protein ECP bakteri

Table 3. M olecular weight of protein for ECP bacteria

\begin{tabular}{cccccc}
\hline \multirow{2}{*}{$\begin{array}{c}\text { Berat molekul } \\
\begin{array}{c}\text { Molecular weight } \\
\text { (kDa) }\end{array}\end{array}$} & \multicolumn{5}{c}{$\begin{array}{c}\text { Perlakuan (kode bakteri) } \\
\text { Treatments (code of bacteria) }\end{array}$} \\
\cline { 2 - 5 } & $\begin{array}{c}\text { B } \\
\text { (NP1050) }\end{array}$ & $\begin{array}{c}\text { I } \\
\text { (SG01-16) }\end{array}$ & $\begin{array}{c}\text { E } \\
\left(\mathbf{N}_{\mathbf{1 4}} \mathbf{G}\right)\end{array}$ & $\begin{array}{c}\text { G } \\
\text { (NTO10) }\end{array}$ & Protein \\
\cline { 2 - 5 } 150.00 & + & + & + & + & Pili backbone protein* \\
79.00 & + & + & - & - & CylE protein** \\
65.92 & + & + & + & + & BL/UD \\
38.66 & + & + & + & + & BL/UD \\
24.00 & + & + & + & + & CAMP protein** \\
19.01 & + & + & + & + & BL/UD \\
17.14 & + & + & + & + & BL/UD \\
15.45 & + & + & - & - & C protein alpha** \\
13.93 & + & + & + & + & BL/UD \\
\hline
\end{tabular}

Keterangan (Note): * Doran \& Nizet (2004); ** Spellerberg et al. (1999); BL/UD: belum diketahui (undetected) 
penghitungan konsentrasi protein menunjukkan konsentrasi protein sel utuh dan ECP bakteri $\beta$ hemolitik lebih tinggi daripada non-hemolitik (Tabel 4).

Bakteri $\beta$-hemolitik memiliki pita protein berbeda dibandingkan non-hemolitik yaitu pita protein dengan BM 79 kDa (cylE protein) diperkirakan identik dengan â-hemolisin/cytolysin dan $15,45 \mathrm{kDa}$ (C protein alpha) (Doran \& Nizet, 2004; Spellerberg et al., 1999). cylEprotein merupakan toksin penting bagi bakteri $\mathrm{S}$. agalactiae untuk menginfeksi inang, menginduksi respons inflamasi, dan berkontribusi terhadap gejala neurologis (Rajagopal, 2009).

Fraksinasi pada ECP teridentifikasi sebanyak tujuh pita protein ( $\beta$-hemolitik) dan empat pita protein (non-hemolitik). Protein pada bakteri $\beta$-hemolitik dengan BM $79 \mathrm{kDa}$ dan $32 \mathrm{kDa}$ diduga identik dengan gen virulen cylE protein dan cylB protein (Doran \& Nizet, 2004; Spellerberg et al., 1999). Semua bakteri memiliki protein dengan BM $85.41 \mathrm{kDa}$ diduga identik dengan gen C protein beta (Doran \& Nizet, 2004), merupakan $\beta$-protein yang memblokir pemusnahan sel intraseluler oleh netrofil (Doran \& Nizet, 2004; Delannoy et al., 2014). Penelitian profil protein ECP NK1 diperoleh sebanyak 13 pita protein dengan BM 18,3-61,33 kDa (Suryadi et al., 2017) sedangkan fraksinasi ECP N ${ }_{14} \mathrm{G}$ menghasilkan dua pita protein dengan BM 21,99 dan 83,42 kDa (Sugiani, 2012). Perbedaan jumlah pita protein kemungkinan karena perbedaan strain dan biotipe bakteri, media kultur, serta lama inkubasi bakteri.

Terdapat perbedaan signifikan nilai konsentrasi protein sel utuh semua bakteri, dengan konsentrasi tertinggi sebesar $0,912 \mathrm{mg} \mathrm{mL}^{-1}$ dihasilkan isolat SG01-16 dan konsentrasi terendah isolat $\mathrm{N}_{14} \mathrm{G}$ sebesar $0,421 \mathrm{mg} \mathrm{mL}^{-1}$. Penelitian konsentrasi protein bakteri $\mathrm{N}_{14} \mathrm{G}$ yang dikultur selama 72 jam diperoleh hasil pada sel utuh sebesar $1,37 \mathrm{mg} \mathrm{mL}^{-1}$ dan ECP sebesar 1,89 $\mathrm{mg} \mathrm{mL}^{-1}$ (Sugiani, 2012).
Pengujian terhadap abno rmalitas dan kematian ikan dilakukan dengan menginjeksikan sel utuh dan ECP bakteri S. agalactiae, hasil pengamatan menunjukkan gejala abnormalitas yaitu melanosis pada ikan nila terjadi pada semua perlakuan (Tabel 5). Ikan yang diinjeksi ECP tipe $\beta$-hemolitik dan non-hemolitik mengalami gejala klinis gasping, ocular opacity, erratic, tubuh membentuk C-shape, whirling, ikan mengalami kekakuan, dan akhirnya mati.

Perbedaan hanya terjadi pada durasi waktu yakni ikan yang diinjeksi ECP bakteri $\beta$-hemolitik melanosis terjadi jam kedua pascainjeksi diikuti gejala lain yaitu ikan bernafas terengah-engah (gasping), berenang tidak menentu (erratic), tubuh ikan membentuk huruf $C$ (C-shape), berenang berputar (whirling), dan kaku. Hasil ini berbeda dengan penelitian Pretto-Giordano et al. (2010); Hardi (2011) menunjukkan ECPS. agalactiae yang diinjeksikan pada ikan nila menyebabkan eksoptalmia di hari kedua pasca-penyuntikan, sedangkan Suryadi et al. (2017) menyatakan gejala klinis berupa perubahan warna tubuh menjadi pucat terjadi pasca-penyuntikan ikan nila pada jam ke-24 dan ke-48.

ECP bakteri non-hemolitik yang diinjeksikan secara IP reaksinya lebih lambat, melanosis pada ikan nila terjadi pada jam ke-8 pascainjeksi, diikuti gejala lain termasuk mata berwarna putih (ocular opacity). Gejala klinis ini hampir sama dengan gejala klinis akibat infeksi bakteri yaitu perdarahan mata, kornea opacity, perut buncit, sumsum tulang belakang melengkung membentuk huruf C, kekakuan (Hardi et al., 2011; Sugiani, 2012). ECP bakteri $\beta$-hemolitik memberikan reaksi yang cepat dalam menyebabkan abnormalitas pada ikan nila. Ikan nila yang diinjeksi sel utuh dan ECP menunjukkan hasil bervariasi berdasarkan perlakuan, kematian awal terjadi pada enam jam pascainjeksi ECP SG01-16. Mortalitas sebanyak 10\% terjadi pada ikan yang diinjeksi ECP N ${ }_{14} \mathrm{G}, 12$ jam pasca-penyuntikan (Gambar 3).

Tabel 4. Konsentrasi protein sel utuh dan ECP S.agalactiae

Table 4. Protein concentration of whole cells and ECP S. agalactiae

\begin{tabular}{ccc}
\hline $\begin{array}{c}\text { Kode bakteri } \\
\text { Code of bacteria }\end{array}$ & $\begin{array}{c}\text { Konsentrasi protein sel utuh } \\
\text { Protein concentration of whole cells } \\
\left(\mathbf{m ~ g ~ m ~}^{-1}\right)\end{array}$ & $\begin{array}{c}\text { Konsentrasi protein ECP } \\
\text { Protein concentration of ECP } \\
\left(\mathbf{m g ~ m L}^{-\mathbf{1}}\right)\end{array}$ \\
\hline NP1050 & $0.909 \pm 0.005^{\mathrm{a}}$ & $0.215 \pm 0.009^{\mathrm{d}}$ \\
$\mathrm{N}_{14} \mathrm{G}$ & $0.421 \pm 0.007^{\mathrm{c}}$ & $0.146 \pm 0.13^{\mathrm{d}}$ \\
$\mathrm{NT010}$ & $0.754 \pm 0.006^{\mathrm{b}}$ & $0.207 \pm 0.008^{\mathrm{d}}$ \\
SG01-16 & $0.912 \pm 0.004^{\mathrm{a}}$ & $0.211 \pm 0.007^{\mathrm{d}}$ \\
\hline
\end{tabular}

Keterangan: Rerata dengan superscript berbeda menunjukkan perbedaan yang signifikan $(p<0,05)$

Note: $\quad$ The mean value with different superscripts showed a significant difference $(p<0.05)$ 
Tabel 5. Gejala klinis pada ikan nila yang diinjeksi sel utuh dan ECP S. agalactiae

Table 5. Clinical signs on tilapia that were injected by whole cells and ECP S. agalactiae

\begin{tabular}{lcccccccc}
\hline \multirow{2}{*}{$\begin{array}{l}\text { Gejala klinis } \\
\text { Clinical signs }\end{array}$} & B & E & G & I & B1 & E1 & G1 & I1 \\
\cline { 2 - 8 } & + & + & + & + & + & + & + & + \\
\hline Melanosis & - & - & - & - & + & + & - & + \\
Gasping & - & - & - & - & - & + & - & - \\
Ocular opacity & - & - & - & - & + & + & - & + \\
Erratic & - & - & - & - & + & + & - & + \\
C-shape & - & - & - & - & + & + & - & + \\
Whirling & - & - & - & - & + & + \\
Kaku (Rigor) & - & - & - & - & + & + & - & + \\
\hline
\end{tabular}

Mortalitas tertinggi terjadi pada perlakuan ECP SG01-16 dan ECP NP1050 sebesar 100\% dan 91\% Rerata waktu kematian mengalami perbedaan yang signifikan yaitu kode perlakuan I1 rerata waktu 9,98 jam; B1 11,44 jam; dan E1 82,29 jam. Hingga masa pemeliharaan selama 21 hari tidak ada kematian pada ikan yang dinjeksi semua sel utuh bakteri S. agalactiae.

ECP berupa toksin yang dihasilkan bakteri $\mathrm{S}$. agalactiae merupakan komponen protein terlarut yang disekresikan bakteri pada fase pertumbuhan eksponensial, biasanya strain virulen menghasilkan toksin protein sebagai penentu utama virulensi (Todar, 2012). Aeromonas hydrophila menghasilkan toksin protein bersifat sitotoksik, sitolitik, hemolitik, dan enterotoksik; dan sangat virulen terhadap ikan nila
(Khalil \& Mansour, 1997), Labeo rohita (Sahu et al., 2011), dan ikan lele (Pridgeon et al., 2013). ECP A. hydrophila menyebabkan kematian sel, sitotoksisitas ginjal, dan hemolisis saat diinjeksikan pada ikan (Grayfer et al., 2014), serta menimbulkan kematian pada ikan rainbow trout (Oncorhynchus mykiss) dalam rentang waktu 5-9 jam pascainjeksi (Nieto et al., 1991). ECP Vibrio harveyi mengandung caseinase, gelatinase, phospholipase, lipase, dan hemolisin menyebabkan kematian sebesar $60 \% 100 \%$ ikan salmon (Salmo salar) (Zhang \& Austin, 2000).

Kematian yang cepat dan banyak pascainjeksi kemungkinan karena banyaknya produk dari gen virulen yang larut dalam ECP, terutama bakteri $\beta$-hemolitik. Penelitian pola kematian pada ikan yang terjadi secara

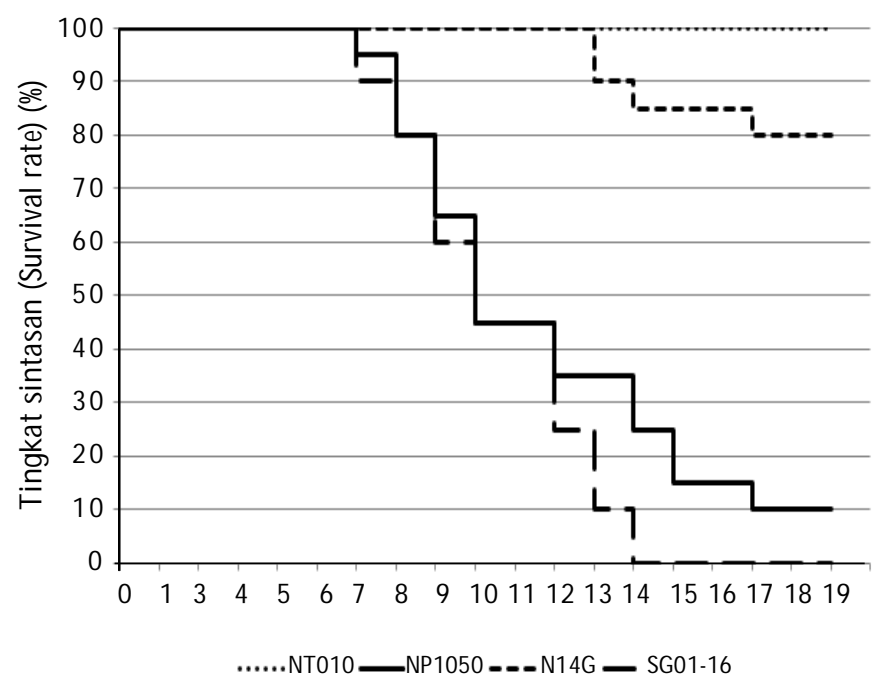

Jam ke- pasca injeksi (Hour post injection)

Gambar 3. Kurva Kaplan-Meier mortalitas ikan pascainjeksi ECP S. agalactiae.

Figure 3. Kaplan-M eier curve of fish mortality post injection by ECP $\mathbf{S}$. agalactiae. 
cepat dan banyak kemungkinan karena keberadaan beberapa enzim seperti hemolisin, lipase, elastase, gelatinase, chitinase dalam ECP (Austin \& Austin, 2007).

Konsentrasi protein pada sel utuh tidak berpengaruh terhadap patogenesitas terhadap ikan nila. Ikan seperti hewan pada umumnya memiliki mekanisme pertahanan diri terhadap patogen (Shoemaker et al., 2015). Sel utuh bakteri yang diinjeksikan ke ikan kemungkinan difagosit oleh sel-sel fagositik yang menghancurkan antigen melalui tiga tahap yaitu pelekatan, fagosit, dan pencernaan.

Toksin protein bakteri masuk ke dalam sel target melalui dua mekanisme, pertama toksin langsung berikatan dengan reseptor spesifik pada sel target dan menginduksi pembentukan pori dalam membran melalui aktivitas enzimatik ditransfer ke sitoplasma sel. Mekanisme kedua yaitu alternatif, toksin berikatan dengan sel target dan struktur toksin dibawa ke dalam sel melalui proses selektivitas dan efektivitas penangkapan makromolekul atau biasa disebut reseptormediated endocytosis (RME) (Todar, 2012). Studi in vitro menggunakan mutan group B Streptococcus (GBS) isogenik bakteri non-hemolitik maupun hiperhemolitik menjelaskan peranan toksin $\beta$-hemolysin/ cytolysin $(\beta-h / c)$ terhadap patogenesis. Produksi $\beta-h / c$ berkorelasi terhadap kerusakan sitolitik pada sel-sel epitel, sel endotel, dan makrofag, dibuktikan dengan berkurangnya kepadatan sitoplasma, pemisahan sito plasma, dan membran inti, dan organel membesar karena adanya mekanisme aksi pembentukan pori. $\beta$ $\mathrm{h} / \mathrm{c}$ menstimulasi transkripsi intraseluler nitric oxide synthase (iNOS) dan produksi nitric oxide (NO) dalam makrofag dan memicu apoptosis makrofag melalui jalur MyD88-independen (Nizet, 2002).
Pengamatan histopatologi pada ikan nila dengan organ target hati, limpa, otak, dan ginjal menunjukkan adanya abnormalitas dengan intensitas bervariasi. Abnormalitas pada hati berupa peradangan sel secara menyeluruh, kongesti sinusoid dan hilangnya hepatosit, nekrosis, pembuluh darah besar pada parenkima tampak berdilatasi dengan lumen terisi selsel darah (kongesti), vakuola-vakuola kosong pada sitoplasma sehingga mendorong nukleus ke tepi (diduga degenerasi) (Gambar 4). Limpa menunjukkan adanya nekrosis, infiltrasi sel radang, pulpa putih germinal centres tidak terlihat, dan degenerasi pulpa merah (Gambar 5), kongesti kapiler pada meninges, pigmen hemosiderin pada sito plasma di jaringan otak (Gambar 6). Kongesti pembuluh darah tampak pada parenkima secara menyeluruh terjadi di ginjal, pendarahan, pembekuan darah di glomeruli dan tubulus, infiltrasi sel-sel radang, serta nekrosis (Gambar 7).

Organ hati mengalami perubahan histopatologi yang menyebabkan terjadinya disfungsi hati sehingga fungsi utama hati untuk detoksifikasi racun atau benda asing menjadi terganggu, ditunjukkan adanya degenerasi yang ditandai hepatosit dan kongesti di sinusoid. Adanya vakuola disebabkan pembengkakan hepatosit, penyempitan sinusoid, akibatnya terjadi pembengkakan sel hati. Infeksi S. agalactiae pada ikan nila menunjukkan pengeluaran hepatosit dengan perubahan lemak sebagai respons terhadap berkurangnya aliran darah karena tersumbatnya aliran darah dan trombosis pembuluh darah portal (Chen et al., 2007; Laith et al., 2017).

Studi histopatologi jaringan otak menunjukkan adanya meningitis, infiltrasi sel inflamasi, disertai pendarahan seperti laporan penelitian Laith et al. (2017). Hasil ini berkorelasi positif pada ikan yang

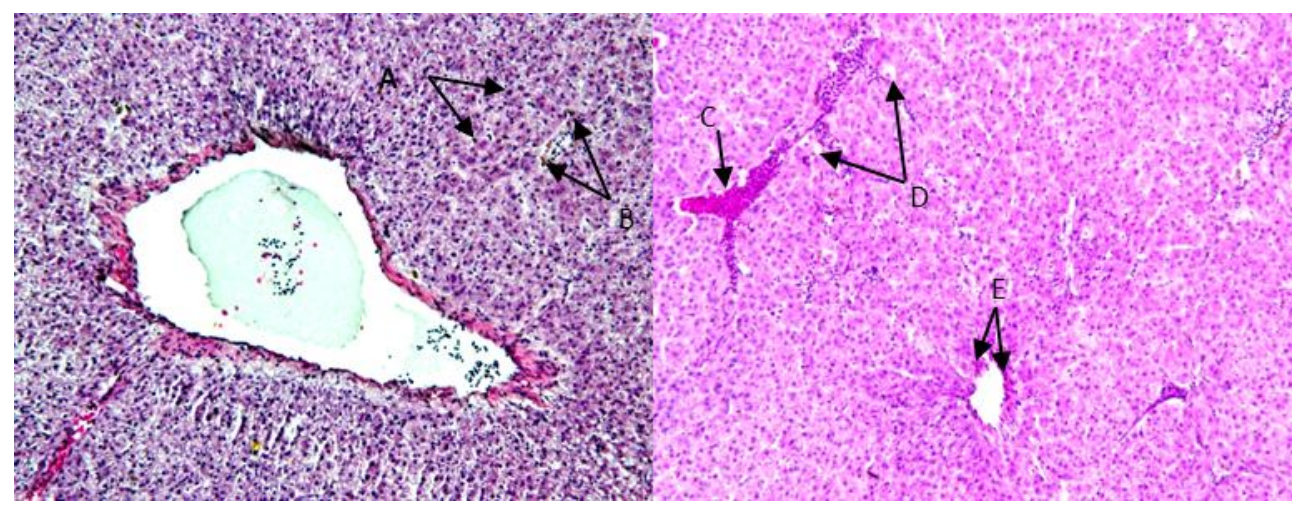

Gambar 4. Hati: peradangan sel (A), nekrosis (B), pendarahan (C), vakuola pada sitoplasma (D), kongesti di sinusoid dan hilangnya hepatosit (E).

Figure 4. $\quad$ Liver: inflammatory cells (A), necrosis (B), hemorrhage (C), vacuole in the cytoplasm (D), congestion of sinusoids and loss of hepatocytes (E). 


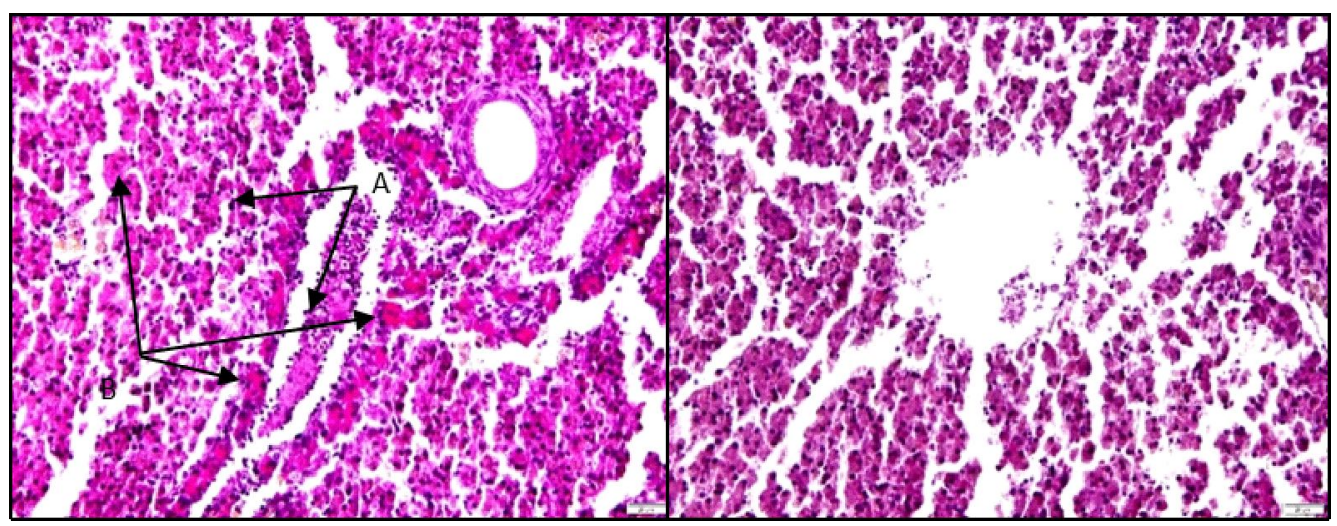

Gambar 5. Limpa: nekrosis (A), infiltrasi sel radang (B).

Figure 5. Spleen: necrocis (A), infiltration of inflammatory cell (B).

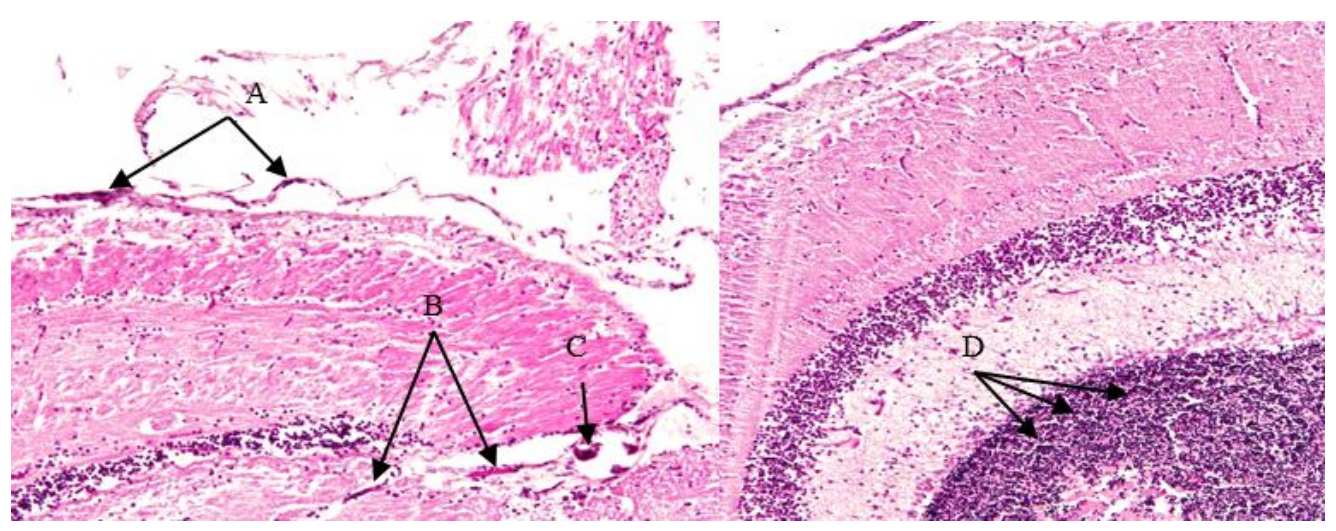

Gambar 6. Otak: kongesti kapiler pada meninges (A), kongesti kapiler (B), pigmen hemosiderin (C), infiltrasi sel radang (D).

Figure 6. Brain: congestion of the meninges (A), capillary congestion (B), hemosiderin pigment (C), infiltration of inflammatory cell (D).

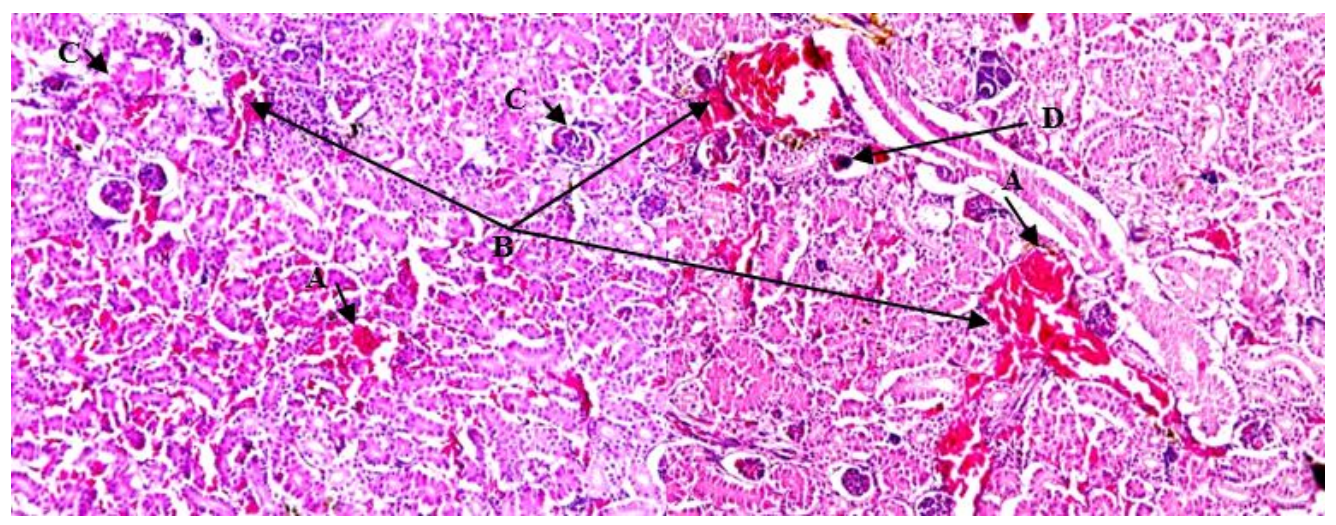

Gambar 7. Ginjal: pembekuan darah (A), pendarahan (B), infiltrasi sel-sel radang (C), nekrosis (D).

Figure 7. Kidney: thrombosis $(A)$, hemorrhage $(B)$, inflammatory cell infiltration $(C)$, necrosis (D). 
diinjeksi ECP mengalami abnormalitas gejala klinis yaitu pola berenang tidak menentu dan berenang berputar. Hasil penelitian Hardi et al. (2011) menyatakan jaringan otak ikan nila yang terserang streptococcosis mengalami kerusakan dan berdampak negatif dengan melemahnya fungsi syaraf, akibatnya ikan berenang memutar (whirling) yang pada akhirnya menyebabkan kematian.

Jaringan limpa menunjukkan periarterial lymphoid sheath (PALS) tampak lebih kecil dari normal dan germinal centers jarang terlihat karena deplesi degenerasi pulpa merah, nekrosis, dan infiltrasi sel radang. Degenerasi pulpa merah menyebabkan fungsi filtrasi pengangkatan sel darah merah yang tua atau rusak dari peredaran menjadi terganggu. Limpa sebagai tempat terjadinya proliferasi hematopoitik dan aktivasi sel fagositik utama, melanomacrophages, mengalami abnormalitas kemungkinan disebabkan peran bakteri dan racun pada ikan yang terinfeksi (Amyes, 2007). Ginjal mengalami kongesti pembuluh darah tampak pada parenkima secara menyeluruh, pendarahan, dan pembekuan darah yang parah disertai infiltrasi sel inflamasi. Kerusakan jaringan hematopoitik ginjal mirip dengan penelitian pada ikan nila merah (Oreochromis sp.) yang diinfeksi dengan S. agalactiae (Su et al., 2017).

\section{KESIMPULAN}

ECP bakteri $\beta$-hemolitik lebih virulen dibandingkan tipe non-hemolitik, sedangkan sel utuh yang diinjeksi pada ikan tidak memberikan dampak kematian. Pengamatan histopatologi ikan yang diinjeksi ECP S. agalactiae pada organ hati, limpa, otak, dan ginjal menunjukkan adanya kongesti, hemoragi, dan nekrosis.

\section{UCAPAN TERIMA KASIH}

Terima kasih kepada Badan Riset Sumberdaya Manusia Kelautan dan Perikanan (BRSDMKP) KKP, BRPBATPP Bogor, IRP2I Depok, Politeknik KP Sorong, BKIPM 1 Jayapura, dan BPBAT Sungai Gelam Jambi.

\section{DAFTAR ACUAN}

Al Harbi, A.H. (2016). Phenotypic and genotypic characterization of Streptococcus agalactiae isolated from hybrid tilapia (Oreochromis niloticus $\times 0$. aureus). Aquaculture, 464, 515-20.

Amal, M.N.A. \& Zamri-Saad, M. (2011). Streptococcosis in tilapia (Oreochromis niloticus): a review. Pertanika Journal of Tropical Agricultural Science, 34(2), 195-206.

Amal, M.N.A., Zamri-Saad, M., Zahrah, A.S., \& Zulkafli, A.R. (2015). Water quality influences the presence of Streptococcus agalactiae in cage cultured red hybrid tilapia, Oreochromis niloticus $x$ Oreochromis mossambicus. Aquaculture Research, 46(2), 313-23.

Amyes, S.G. (2007). Enterococci and streptococci. International Journal of Antimicrobial Agents, 29, S43S52.

Austin, B. \& Austin, D.A. (2007). Bacterial fish pathogens. Fourth Edition. p. 552. New York: Praxis Publishing Ltd., $552 \mathrm{pp}$.

Bradford, M.M. (1976). A rapid and sensitive method for the quantitation of microgram quantities of protein utilizing the principle of protein-dye binding. Analytical Biochemistry, 72(1-2), 248-254.

Chen, C., Chao, C., \& Bowser, P.R. (2007). Comparative histopathology of Streptococcus iniae and Streptococcus agalactiaeinfected tilapia. Bulletin-European Association of Fish Pathologists, 27(1), 1-9.

Delannoy, C.M.J., Zadoks, R.N., Crumlish, M., Rodgers, D., Lainson, F.A., Ferguson, H.W., \& Fontaine, M.C. (2014). Genomic comparison of virulent and non-virulent Streptococcus agalactiae in fish. Journal of Fish Diseases, 39(1), 13-29.

Doran, K.S. \& Nizet, V. (2004). Molecular pathogenesis of neonatal group B streptococcal infection: no longer in its infancy. Molecular Microbiology, 54(1), 23-31.

Grayfer, L., Hodgkinson, J.W., \& Belosevic, M. (2014). Antimicrobial responses of teleost phagocytes and innate immune evasion strategies of intracellular bacteria. Developmental \& Comparative Immunology, 43(2), 223-242.

Hardi, E.H. (2011). Kandidat vaksin potensial Streptococcus agalactiae untuk pencegahan penyakit streptococcosis pada ikan nila (Oreochromis niloticus). Disertasi. Sekolah Pascasarjana Institut Pertanian Bogor.

Hardi, E.H., Sukenda, Harris, E., \& Lusiastuti, A.M. (2011). Karakteristik dan patogenisitas Streptococcus agalactiae tipe $\beta$-hemolitik dan non-hemolitik pada ikan nila. Jurnal Veteriner, 12(2), 152-164.

Kannika, K., Pisuttharachai, D., Srisapoome, P., Wongtavatchai, J., Kondo, H., Hirono, I., Unajak, S., \& Areechon, N. (2017). Molecular serotyping, virulence gene profiling and pathogenicity of Streptococcus agalactiae isolated from tilapia farms in Thailand by multiplex PCR. Journal of Applied Microbiology, 122(6), 1497-1507.

Kayansamruaj, P., Pirarat, N., Katagiri, T., Hirono, I., $\&$ Rodkhum, C. (2014). Molecular characterization and virulence gene profiling of pathogenic Streptococcus agalactiae populations from tilapia (Oreochromis sp.) farms in Thailand. Journal of Veterinary Diagnostic Investigation, 26(4), 488-495. 
Kayansamruaj, P., Pirarat, N., Kondo, H., Hirono, I., \& Rodkhum, C. (2015). Genomic comparison between pathogenic Streptococcus agalactiae isolated from nile tilapia in Thailand and fish-derived ST7 strains. Infection, Genetics and Evolution, 36, 30714.

Khalil, A.H. \& Mansour, E.H. (1997). Toxicity of crude extracellular products of Aeromonas hydrophila in tilapia, Tilapia nilotica. Letters in Applied Microbiology, 25(4), 269-273.

Laemmli, U.K. (1970). Cleavage of structural proteins during the assembly of the head of bacteriophage T4. Nature, 227, 680-685.

Laith, A.A., Ambak, M.A., Hassan, M., Sheriff, S.M., Nadirah, M., Draman, A.S., Wahab, W., Wan Ibrahim, W.N., Aznan, A.S., Amina Jabar, A., \& Najiah, M. (2017). Molecular identification and histopathological study of natural Streptococcus agalactiae infection in hybrid tilapia (Oreochromis niloticus). Veterinary World, 10(1), 101-111

Li, Y.W., Liu, L., Huang, P.R., Fang, W., Luo, Z.P., Peng, H.L., \& Li, A.X. (2014). Chronic streptococcosis in nile tilapia, Oreochromis niloticus (L.), caused by Streptococcus agalactiae. Journal of Fish Diseases, 37(8), 757-763.

Lusiastuti, A.M., Textor, M., Seeger, H., Akineden, Ö., $\&$ Zschöck, M. (2014). The occurrence of Streptococcus agalactiae sequence tipe 261 from fish disease outbreaks of tilapia Oreochromis niloticus in Indonesia. Aquaculture Research, 45, 1260-1263.

Nieto, T.P., Santos, Y., Rodriguez, L.A., \& Ellis, A.E. (1991). An extracellular acetylcholinesterase produced by Aeromonas hydrophila is a major lethal toxin for fish. Microbial pathogenesis, 11(2), 101110.

Nitimulyo, K.H., Isnansetyo, A., Triyanto, T., Murdjani, M., \& Sholichah, L. (2005). Efektivitas vaksin polivalen untuk pengendalian vibriosis pada kerapu tikus (Cromileptes altivelis). Jurnal Perikanan Universitas Gadjah Mada, 7(1), 95-100.

Nizet, V. (2002). Streptococcal â-hemolysins: genetics and role in disease pathogenesis. Trends in Microbiology, 10(12), 575-580.

Noraini, O., Sabri, M.Y., \& Siti Zahrah, A. (2013). Efficacy of spray administration of formalin killed Streptococcus agalactiae in hybrid red tilapia. Journal of Aquatic Animal Health, 25(2), 142-148.

Pereira, U.P., Santos, A.R., Hassan, S.S., Aburjaile, F.F., Soares, S.C., Ramos, R.T.J., Carneiro, A.R., Guimaraes, L.C., Diniz, C.A.A., Barbosa, M.S., de Sa, P.B., Ali, M., Bakhtiar, S.M., Dorella, F.A., Zerlotini, A., Araujo, F.M.G., Leite, L.R., Oliviera, G., Miyoshi, A., Silva, A., Azevedo, V., \&
Figueiredo, H.C.P. (2013). Complete genome sequence of Streptococcus agalactiae strain SA20-06, a fish pathogen associated to meningoencephalitis outbreaks. Standards in Genomic Sciences, 8(2), 188.

Pradeep, P.J., Suebsing, R., Sirthammajak, S., Kampeera, J., Jitrakorn, S., Saksmerprome, V., \& Jeffs, A. (2016). Evidence of vertical transmission and tissue tropism of Streptococcosis from naturally infected red tilapia (Oreochromis spp.). Aquaculture Reports, 3, 58-66.

Pretto-Giordano, L.G., Müller, E.E., Freitas, J.C.D., \& Silva, V.G.D. (2010). Evaluation on the pathogenesis of Streptococcus agalactiae in nile tilapia (Oreochromis niloticus). Brazilian Archives of Biology and Technology, 53(1), 87-92.

Pridgeon, J.W., Klesius, P.H., Song, L., Zhang, D., Kojima, K., \& Mobley, J.A. (2013). Identification, virulence, and mass spectrometry of toxic ECP fractions of West Alabama isolates of Aeromonas hydrophila obtained from a 2010 disease outbreak. Veterinary Microbiology, 164(3-4), 336-343.

Rajagopal, L. (2009). Understanding the regulation of Group B Streptococcal virulence factors. Future Microbiology, 4(2), 201-21.

Rosini, R. \& Margarit, I. (2015). Biofilm formation by Streptococcus agalactiae: influence of environmental conditions and implicated virulence factors. Frontiers in Cellular and Infection Microbiology, 5(6), 1-4.

Sahu, I., Das, B.K., Marhual, N., Samanta, M., Mishra, B.K., \& Eknath, A.E. (2011). Toxicity of crude extracellular products of Aeromonas hydrophila on rohu, Labeo rohita (Ham.). Indian Journal of Microbiology, 51(4), 515-520.

Sheehan, B., Labrie, L., Lee, Y.S., Wong, F.S., Chan, J., Komar, C., Wendover, N., \& Grisez, L. (2009). Streptococcal diseases in farmed tilapia. Aquaculture Asia Pacific, 5, 26-29.

Shoemaker, C., LaFrentz, B., \& LaPatra, S. (2015). Overview of fish immune system and infectious diseases. Dietary nutrients, additives and fish health. Wiley, Canada, p. 1-24.

Standar Nasional Indonesia [SNI]. 7545.3. (2009). Metode identifikasi bakteri pada ikan secara konvensional - Bagian 2.

Spellerberg, B., Pohl, B., Haase, G., Martin, S., Weber-Heynemann, J., \& Lütticken, R. (1999). Identification of genetic determinants for the hemolytic activity of Streptococcus agalactiae by ISS1 transposition. Journal of Bacteriology, 181(10), 32123219. 
Su, Y., Feng, J., Liu, C., Li, W., Xie, Y., \& Li, A. (2017). Dynamic bacterial colonization and microscopic lesions in multiple organs of tilapia infected with low and high pathogenic Streptococcus agalactiae strains. Aquaculture, 471, 190-203.

Sugiani, D. (2012). Vaksin bivalen untuk pencegahan penyakit motile aeromonas septicemia dan streptococcosis pada ikan nila (Oreochromis niloticus). Disertasi. Sekolah Pascasarjana Institut Pertanian Bogor.

Sukenda, Rusli, Nuryati, S., \& Hidayatullah, D. (2015). Durasi proteksi vaksin Streptococcus agalactiae untuk pencegahan streptococcosis pada ikan nila. Jurnal Akuakultur Indonesia, 14(2), 192-201.

Suryadi, I.B.B., Sukenda, \& Nuryati, S. (2017). Fraksinasi dan uji toksisitas ECP (extracellular product) Streptococcus agalactiae isolat NK1 pada ikan nila (Oreochromis niloticus). Jurnal Perikanan Kelautan, 8(1), 122-129.
Taukhid, \& Purwaningsih, U. (2009). Penapisan isolat bakteri Streptococcus spp. sebagai kandidat antigen dalam pembuatan vaksin, serta efikasinya untuk pencegahan penyakit streptococciasis pada ikan nila, Oreochromis niloticus. Jurnal Riset Akuakultur, 6(1), 103-118.

Todar, K. (2012). Bacterial protein toxins. Todar's Online Textbook of Bacteriology. Madison, Wisconsin.

Williams, M.L., Azadi, P., \& Lawrence, M.L. (2003). Comparison of cellular and extracellular products expressed by virulent and attenuated strains of Edwardsiella ictaluri. Journal of Aquatic Animal Health, 15, 264-273.

Zhang, X.H. \& Austin, B. (2000). Pathogenicity of Vibrio harveyi to salmonids. Journal of Fish Diseases, 23(2), 93-102. 